\title{
Clinical Trial of Glibornuride in Diabetes
}

\author{
A. W. LOGIE, J. M. STOWERS
}

British Medical fournal, 1975, 3, 514-515

\section{Summary}

Glibornuride is an addition to the second-generation sulphonylureas, that has been shown in clinical trials to be effective and non-toxic. Twenty-three diabetics who were poorly controlled on other oral hypoglycaemic agents and seven newly diagnosed diabetics were treated with glibornuride. The efficacy and lack of toxicity of this drug was confirmed, but there was no evidence to suggest that it is significantly more potent than other sulphonylureas. It does not seem to represent a significant therapeutic advance.

\section{Introduction}

Glibornuride (Glutril) is a sulphonylurea derivative which has been used as a hypoglycaemic agent in several countries for some years, though it has not yet been marketed in the United Kingdom. Given by mouth, it is rapidly and almost completely (98\%) absorbed from the gut and is highly but reversibly protein-bound $(95 \%)$ in the circulation. It has a half life of about eight hours, being broken down in the liver to inactive metabolites that are excreted mainly by the kidney. On the basis of extensive clinical trials ${ }^{12}$ it has been claimed to be non-toxic, safe, and effective in the treatment of maturity onset diabetes.

Several second-generation sulphonylureas are now available, and conflicting claims have been made about their relative value. Since the incidence of toxicity and side effects on the sulphonylureas are low it is difficult to prove a significant advantage for a new compound in this respect. In assessing the place of a sulphonylurea the main concern is with the relative potency, though other pertinent comparative factors are speed and duration of action and the tendency to excessive accumulation of the drug in the presence of azotaemia. We attempted to assess glibornuride by studying its effect in a group of diabetics, most of whom were poorly controlled and at risk of secondary failure on treatment with other sulphonylureas.

\section{Patients and Methods}

We selected patients whose diabetes was poorly controlled on the maximum effective dose of chlorpropamide $(500 \mathrm{mg})$, tolazamide $(750 \mathrm{mg})$, or glibenclamide $(20 \mathrm{mg})$, with or without a biguanide. In all cases the blood urea was below $10.0 \mathrm{mmol} / \mathrm{l}(60 \mathrm{mg} / 100 \mathrm{ml})$. The body weights of all patients were below the 75 th centile for age, sex, and height (after $\mathrm{Kemsley}^{3}$ ) and dietary management remained unaltered throughout. With their informed consent, these patients had their sulphonylurea treatment changed to glibornuride 75-100 $\mathrm{mg} /$ day as a single or twice daily dose. Patients already taking a biguanide continued on the same dose of that drug. The glibornuride tablets were issued from the clinic, which constituted a guide to the regularity of tablet taking, though no formal tablet count was made. Initially patients were reviewed at least once a month and routine observations were made of body weight, fasting glycosuria, ketonuria,

Diabetic Clinic, Aberdeen Royal Infirmary, Aberdeen AB9 1GS

A. W. LOGIE, M.B., M.R.C.P., Senior Medical Registrar

J. M. STOWERS, M.D., F.R.C.P., Consultant Physician and capillary blood sugar (Hoffman method ${ }^{4}$ ) timed in relation to the last meal. Before starting glibornuride and on each review during treatment samples were taken for haemoglobin and full blood count, serum urea and liver function tests, and urinary microscopy and culture (using boric acid as a preservative for the cells in the midstream specimen of urine ${ }^{5}$ ). Changes in drug dosage were made as indicated by clinical response and glibornuride was discontinued if control of diabetes was unsatisfactory. Some newly diagnosed diabetics were also started on glibornuride, initially $25 \mathrm{mg} /$ day.

\section{Results}

Of the 30 patients, 18 men and 12 women aged 20-81 years (mean 51.7 years), who were treated with glibornuride 23 were previously poorly controlled on chlorpropamide, tolazamide, or glibenclamide; $11 \mathrm{had}$ also been treated with metformin $1 \cdot 0-3 \cdot 0 \mathrm{~g} /$ day. The remaining seven patients were newly diagnosed diabetics. Thirteen patients (table I) were still on glibornuride after a mean of 18 months, and 17 patients were withdrawn from the drug after a mean of 5.2 months because of poor control. Table II shows the modified criteria we used to assess the degree of control of diabetes (after Müller et al. ${ }^{6}$ ). We applied these levels of blood sugar timed in relation to meals to assess the quality of control in the 13 patients who were still on treatment at the time of writing (table III). Control was "excellent" in the four newly diagnosed diabetics on a dose of $12 \cdot 5-75 \mathrm{mg} /$ day. Control was improved in eight of the nine patients transferred from other sulphonylureas, though in two cases (cases 5 and 9) the improvement was mainly attributable to the addition of metformin and in a third partly due to this (case 11). In case 6 the dose of metformin was reduced. The patient who showed no improvement was uncooperative with dietary matters and refused insulin treatment; he was hyperglycaemic but not ketotic.

TABLE II-Criteria for Degree of Control (After Müller et al. ${ }^{6}$ )

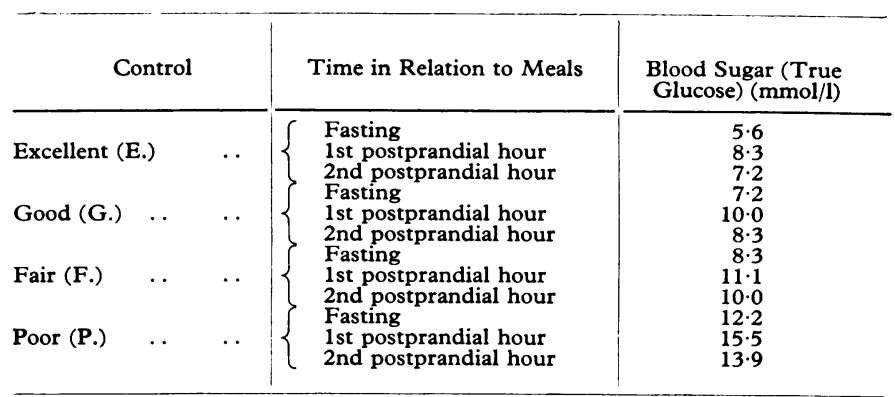

Conversion: SI to Traditional Units
Glucose: $1 \mathrm{mmol} / \mathrm{l} \approx 18 \mathrm{mg} / 100 \mathrm{ml}$.

Seventeen patients were withdrawn from treatment with glibornuride $100 \mathrm{mg}$ /day because of poor control after a mean of 5.2 months-(table I). All these patients were hyperglycaemic and some were losing weight but none was clinically or biochemically ketotic. Three patients were primary failures of sulphonylurea and at an age $(20,23$, and 24 years) not usually associated with satisfactory response to oral treatment. Similarly, two of the patients with secondary failure were aged 35 years when started on glibornuride; one had been treated for overt diabetes with chlorpropamide for five years and the other with tolazamide for one and a half years, and both could be expected to be at high risk of secondary failure because of their relative youth. Metformin ( $0.5-3 \mathrm{~g} /$ day) was added to glibornuride in five patients with secondary failure and in each case produced only temporary improvement; a further seven patients were already taking metformin in addition to sulphonylurea at the time of transfer to glibornuride; the metformin dose was not changed. Of the 12 patients with secondary failure who had been transferred from other drugs 
TABLE I-Details of 13 Patients who Continued on Glibornuride and 17 Patients in whom Treatment Failed

\begin{tabular}{|c|c|c|c|c|c|c|c|}
\hline \multirow{2}{*}{\multicolumn{3}{|c|}{ Previous Treatment }} & \multirow{2}{*}{$\begin{array}{l}\text { No. of } \\
\text { Patients }\end{array}$} & \multicolumn{2}{|c|}{ Continuing on Glibornuride } & \multicolumn{2}{|c|}{ Failure of Treatment } \\
\hline & & & & $\begin{array}{l}\text { No. of Patients } \\
\text { (Dose; mg/day) }\end{array}$ & $\begin{array}{c}\text { Mean Duration (Range) } \\
\text { of Treatment } \\
\text { (Months) }\end{array}$ & $\begin{array}{c}\text { No. of Patients } \\
\text { (No. of Primary Failures) }\end{array}$ & $\begin{array}{c}\text { Mean Duration (Range) } \\
\text { of Treatment } \\
\text { (Months) }\end{array}$ \\
\hline $\begin{array}{l}\text { None } \ldots \\
\text { Tolazamide }(750 \mathrm{mg}) \\
\text { Cblorpropamide }(500 \mathrm{mg}) \\
\text { Glibenclamide }(20 \mathrm{mg})\end{array}$ & $\begin{array}{l}\cdots \\
\cdots \\
\cdots\end{array}$ & $\begin{array}{l}\cdots \\
\cdots \\
\cdots\end{array}$ & $\begin{array}{r}7 \\
11 \\
8 \\
4\end{array}$ & $\begin{array}{l}4(12 \cdot 5-75) \\
5(100) \\
2(100) \\
2(100)\end{array}$ & $\begin{array}{l}18 \cdot 8(11-25) \\
13 \cdot 6(8-17) \\
20(14-26) \\
25 \cdot 5(25-26)\end{array}$ & $\begin{array}{l}3(1) \\
6(1) \\
6(1) \\
2\end{array}$ & $\begin{array}{l}3.4 \text { ( } 5 \text { weeks }-5 \text { months }) \\
3.8 \text { (1 week-9 months) } \\
9 \text { ( } 2 \text { weeks }-26 \text { months }) \\
1.5(1-2 \text { months })\end{array}$ \\
\hline Total & & & 30 & 13 & $18(8-26)$ & 17 & $5 \cdot 2$ ( 1 week-26 months) \\
\hline
\end{tabular}

TABLE III-Progress in 13 Patients who Continued on Glibornuride

\begin{tabular}{|c|c|c|c|c|c|c|c|c|}
\hline \multicolumn{2}{|c|}{ Previous Treatment } & \multirow{2}{*}{$\begin{array}{c}\begin{array}{c}\text { No. of } \\
\text { Patients }\end{array} \\
4\end{array}$} & \multirow{2}{*}{$\begin{array}{c}\begin{array}{c}\text { No. with } \\
\text { Improved } \\
\text { Control }\end{array} \\
4\end{array}$} & \multicolumn{2}{|c|}{ Biguanide Status } & \multicolumn{3}{|c|}{ Degree of Control before and during Glibornuride Treatment* } \\
\hline None & $\ldots$ & & & \multirow{2}{*}{$\begin{array}{c}\begin{array}{c}\text { No. on Metformin } \\
\text { before Change }\end{array} \\
2\end{array}$} & $\begin{array}{l}\text { No. in whom Metformin } \\
\text { was Added }\end{array}$ & 1 & & $\begin{array}{c}\text { During } \\
\text { E. }\end{array}$ \\
\hline & & & & & & $\begin{array}{l}2 \\
3 \\
4\end{array}$ & & $\begin{array}{l}\text { E. } \\
\text { E. } \\
\text { E. }\end{array}$ \\
\hline Tolazamide. . & . & 5 & 5 & 2 & 2 & $\begin{array}{l}5 \\
6 \\
7 \\
8 \\
9\end{array}$ & $\begin{array}{l}\text { P. } \\
\text { F. } \\
\text { F. } \\
\text { F. }\end{array}$ & $\begin{array}{l}\text { E. } \\
\text { E. } \\
\text { E. } \\
\text { G. }\end{array}$ \\
\hline Chlorpropamide & . & 2 & 2 & 1 & 1 & 10 & P. & F. \\
\hline Glibenclamide & . & 2 & 1 & 2 & & $\begin{array}{l}11 \\
12 \\
13\end{array}$ & $\begin{array}{l}\text { P. } \\
\text { F. }\end{array}$ & $\begin{array}{l}\text { F. } \\
\text { G. }\end{array}$ \\
\hline
\end{tabular}

* See table II tor definitions of degrees of control.

four were worse on glibornuride than on either tolazamide (two patients) or chlorpropamide (two patients), while the other eight patients showed no significant deterioration from control on tolazamide (three patients), chlorpropamide (three patients), or glibenclamide (two patients). Fourteen of the 17 patients were on insulin treatment at the time of writing and the other three were transferred to glibenclamide. Two of these three patients had shown no significant change in control on transfer from tolazamide $(750 \mathrm{mg} /$ day) to glibornuride ( $100 \mathrm{mg} /$ day), and they were later better controlled and stabilized on glibenclamide $20 \mathrm{mg} /$ day and $12.5 \mathrm{mg} /$ day.

\section{SIDE EFFECTS AND TOXICITY}

No patient complained of side effects or admitted to any on direct questioning. One patient was found on routine check before starting glibornuride to have neutropenia and thrombocytopenia. This progressed to a complete aplastic anaemia and was attributed to a course of phenylbutazone for superficial phlebitis. Regular haematological, biochemical, and bacteriological screening showed no evidence of drug toxicity in any other patients.

\section{Discussion}

Glibornuride provided improved and adequate control of diabetes over a mean of $17 \cdot 7$ months in eight out of 23 patients whose control by Müller et al.'s criteria ${ }^{6}$ was fair or poor on other sulphonylureas. In three of these eight patients improvement was partly related to the introduction of metformin. A ninth patient remained on the drug at the time of writing; his control was fair but no worse than when on glibenclamide. The control of four new diabetics who remained on treatment was excellent after a mean of 18.3 months. Any patient whose control remained poor after a reasonable trial of glibornuride, or who developed primary symptoms of diabetes, was changed to other treatment. Thus 17 patients were withdrawn after a mean of 5.2 months; 14 were changed to insulin, the other three being controlled with glibenclamide.

In this trial we aimed to assess the potency of glibornuride relative to other sulphonylureas and, therefore, a deliberately biased selection was made: most of the patients were developing secondary failure on other drugs and the three patients who developed primary failure were all at an age (early 20s) not usually associated with a satisfactory response to oral treatment. From such small numbers we cannot be categorical about comparative potency, but our results do not confirm claims ${ }^{1}$ that glibornuride is more potent than any other sulphonylurea. Schöffling et al. ${ }^{2}$ in a trial of glibornuride in 162 patients, 59 of whom had previously been on glibenclamide, suggested that the two drugs are equivalent in effectiveness and low failure rate, and our results support this conclusion. We found, in several patients, improved control using glibornuride $100 \mathrm{mg} /$ day compared with $75 \mathrm{mg} /$ day, and we therefore do not agree with other workers ${ }^{12}$ that the maximum effective dose is lower than this.

Glibornuride's short half life of about eight hours and its breakdown in the liver to inactive compounds indicate that it is relatively safe for elderly diabetics and those with renal impairment.

We conclude that glibornuride is an effective and safe addition to the range of sulphonylureas but that it is not significantly more potent than existing drugs in most cases and, therefore, does not represent a significant therapeutic advance. The cost at which it will be marketed in this country will have an important bearing on its competitiveness.

We thank the patients for their co-operation in the study, which involved extra investigations and clinic visits, and the medical, nursing, and secretarial staff for help in running the trial. Special arrangements were made for the routine investigations in the departments of chemical pathology, bacteriology, and haematology, University of Aberdeen. The glibornuride tablets were supplied by Roche Products Ltd. who also provided financial support.

\section{References}

1 Bückırt, A., and Schweda, E., Proceedings of the 2nd International Donau Symposium on Diabetes Mellitus, p. 367. Budapest, Vienna Academy of Medicine, 1971.

2 Schöffling, K., et al., Deutsche Medizinische Wochenschrift, 1973, 98, 915.

3 Kemsley, W. F. F., Annals of Eugenics, 1951-2, 16, 316.

4 Hoffman, W. S., fournal of Biochemistry, 1937, 120, 51.

5 Porter, I. A., and Brodie, J., British Medical fournal, 1969, 2, 353.

${ }^{6}$ Müller, R., et al., Hormone and Metabolic Research, 1969, 1, Suppl. p. 88. 